
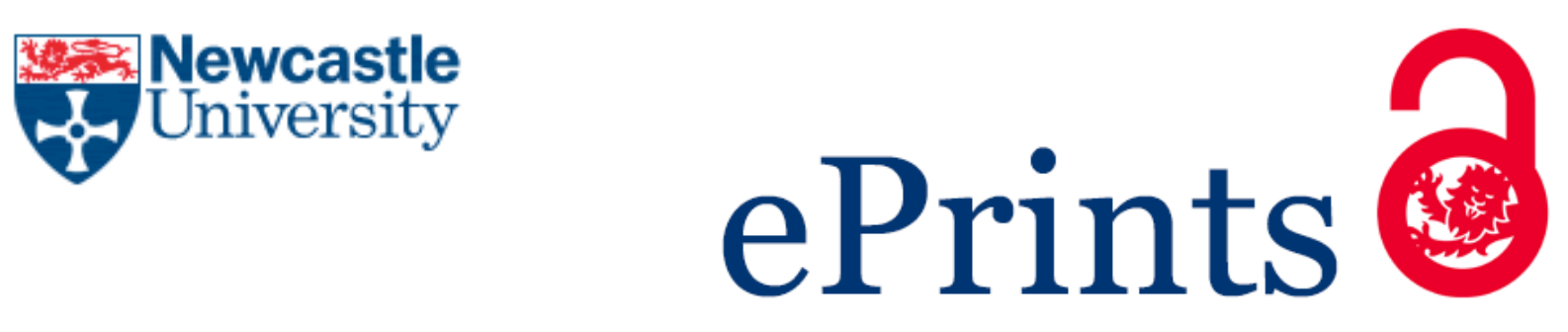

Ward I.

Uneasy Heads: The Play of Law and History in Brenton's 55 Days. Law and Humanities 2016, 10(1), 59-89.

\title{
Copyright:
}

This is an Accepted Manuscript of an article published by Taylor \& Francis in Law and Humanities on 25/05/2016, available online: http://dx.doi.org/10.1080/17521483.2016.1174415

Date deposited:

$29 / 09 / 2016$

Embargo release date:

25 November 2017

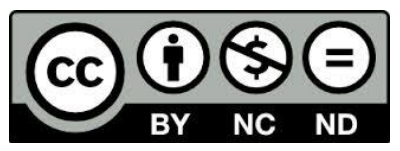

This work is licensed under a

Creative Commons Attribution-NonCommercial-NoDerivatives 4.0 International licence 


\section{Uneasy Heads: the Play of Law and History in Brenton's 55 Days}

The idea that the theatre might provide a space within which to revisit the interplay of law and history is hardly new. Shakespeare built his reputation on the supposition, writing two historical tetralogies chronicling the reigns of Richard II and the Henries IV, V and VI during the earlier part of his career in the 1590s. Each moved ultimately around the question of what made for a good, or conversely a bad, king. To a considerable extent the great tragedies which followed, Hamlet, King Lear, Macbeth, were written to the same purpose. And, at the very end of his career, as he penned the final lines to plays such as The Winter's Tale and The Tempest, the Bard was clearly struggling with pretty much the same themes which had animated his first forays into English history two decades earlier. The nature of kingship, both its human dimension and its institutional form, proved to be intractable. A generation after Shakespeare's death the country would go to war with itself as a consequence. Four centuries on, it puzzles us still; and evidently it makes for just as good drama.

Howard Brenton's 55 Days was first performed at the Hampstead Theatre in October 2012. ${ }^{1}$ Its subject-matter is the events which led up to the execution of Charles I on January $30^{\text {th }} 1649$. The fifty-five days referent establishes dramatic, and in a sense, historical margins. Fifty-five days earlier the Army, under the instruction of Cromwell's son-in-law Henry Ireton, had purged Parliament, removing those Presbyterian MPs who had rejected a proposal in the November Army Remonstrance to bring the king to trial. ${ }^{2}$ It has become known as Pride's Purge, so-named after the Colonel who commanded the troops who barred entry to the Commons. These margins are not of course stable; historical margins rarely are. The events which led up to the execution of the King can be traced long before December $6^{\text {th }} 1648$, and their consequences were to be felt long after January $30^{\text {th }}$. But the historical focus serves its purpose; concentrating our attention on the days and weeks which led up to one of the most dramatic moments in English history. The purpose of this article is to revisit these events through the perspective of Brenton's play. The first part will engage the broader historical and cultural context, revisiting both the politics and the poetics of regicide. The second and third parts will then take a closer look at Brenton's interpretation of the same in 55 Days. The concluding part will then reflect a little further on the larger purpose which underpins Brenton's play.

\section{Wrong but Wromantic}

If the thought that the theatre might be a suitable place within which to contemplate English constitutional history is hardly new, precisely the same might be said of the inverse supposition; that the English constitution might be best appreciated as a dramatic expression. In his English

$1 \quad$ Directed by Howard Davies, whose work attracted particular critical approval; 'excellent' according to Michael Billington in the Guardian. See http://www.theguardian.com/state/2012/oct/25/55-days-review.

$2 \quad$ Whilst Ireton instructed Pride contemporaries surmised, probably correctly, that the purge could not have happened without the approval of Cromwell. Certainly the republican Sir Henry Vane held Cromwell responsible. Forty-one MPs were detained by the Army, being first held in a cell at Westminster and then removed to a couple of local taverns. The rest were merely told to go home. The most famous of the detainees was the preacher William Prynne, a long-standing critic of Army radicalism. It was, according to one recent commentator, a 'very English coup'. The definitive account remains D.Underdown, Pride's Purge: Politics in the Puritan Revolution, (Oxford UP, 1985), 143-72. See also G.Robertson, The Tyrannicide Brief, (Vintage, 2006), 118, and also T.Royle, Civil War: The Wars of the Three Kingdoms 1638-1660, (Little Brown, 2004), 474-8, 4845, and A.Fraser, Cromwell: Our Chief of Men, (Mandarin, 1989), 270-1. 
Constitution, the first edition of which was published in 1867, Walter Bagehot repeatedly averred to its 'theatrical' elements, those aspects 'which appeal to the senses, which claim to be embodiments of the greatest human ideas'. ${ }^{3}$ It is these aspects which lend a necessary 'dignity' to the constitution, and which encourage a natural propensity to defer. In a famous passage Bagehot confirmed that:

In fact, the mass of the English people yield a deference rather to something else than to their rulers. They defer to what we may call the theatrical show of society. A certain state passes before them; a certain pomp of great men; a certain spectacle of beautiful women; a wonderful scene of wealth and enjoyment is displayed, and they are coerced by it. ${ }^{4}$

Eighty years earlier Edmund Burke had said much the same in his Reflections on the Revolution in France. The great historians are dramatists. They appreciate that 'theatre' is so often the 'better school of moral sentiment'. ${ }^{5}$ They appeal to the senses, knowing that it is only 'natural' that their readers will:

be affected by such spectacles with melancholy sentiments upon the unstable condition of moral prosperity, and the tremulous uncertainty of human greatness; because in those natural feelings we learn great lessons; because in events like these our passions instruct our reason; because when kings are hurl'd from their thrones by the Supreme Director of this great drama, and become the objects of insult to the base, and of pity to the good, we behold such disasters in the moral, as we should behold a miracle in the physical order of things. ${ }^{6}$

Like all Whig historians Burke had to be judicious in regard to the hurling of monarchs. The hurling of Marie Antoinette in October 1789 was thoroughly regrettable. By way of contrast the hurling of the English King James II in 1688 was a thoroughly good thing, the necessary precursor to the 'great and glorious' revolution and that 'most wise, sober, and considerate document', the Declaration of Right, which had reaffirmed the essentially Whiggish components of the English constitution. ${ }^{7}$ The entire purpose of Burke's Reflections was to justify this particular reaffirmation, of the 'liberties' of the 'ancient' constitution understood as an 'an entailed inheritance', one that was 'locked fast as in a sort of family settlement; grasped as in a kind of mortmain for ever'. ${ }^{8}$ Accommodating the entail with the realities of revolution was, of course, the defining challenge of Whig historiography. In Reflections, Burke alluded to 'a condition of unchangeable constancy' which 'moves on through the varied tenor of perpetual decay, fall, renovation, and progression'. ${ }^{9}$

The Reflections was ostensibly written as a rebuttal of Joseph Price's Sermon on the Love of Our Country; and there was a very particular historical inference. The Sermon, Burke alleged, was written 'in a strain which I believe has not been heard in this kingdom, in any of the pulpits which are tolerated or encouraged in it, since the year 1648, when a predecessor of Dr Price, the Reverend Hugh Peter' invoked a perverse scripture to urge his countrymen to 'bind their king with chains, and

P.Smith (ed), Bagehot: The English Constitution, (Cambridge UP, 2001), 7.

Bagehot, Constitution 30.

E.Burke, Reflections on the Revolution in France, (Penguin, 1986), 285.

Burke, Reflections, 175.

Burke, Reflections, 100.

Burke, Reflections, 119-20.

Burke, Reflections, 120. 
their nobles with fetters of iron' ${ }^{10}$ Whilst the hurling of James II might be defensible that of his father was rather more difficult to reconcile. Burke might have despaired of certain kings, but he never despaired of the idea of a British monarchy. The Crown set the 'frame to the commonwealth', binding all together in common cause regardless of the 'inevitable tendency to party tyranny' which representative democracy, no matter how limited, nurtures. ${ }^{11}$ Not everyone was so sure of course. Tom Paine famously was not.

And a generation later Thomas Carlyle would evince a rather more round-headed attitude too. Carlyle's histories were famously the histories of men who mattered. Cromwell mattered. Wellington mattered. Not many other Victorians did, at least not in the same way. Carlyle's larger purpose, just as famously, was to somehow inspire a new generation of heroes; or at least one or two. Here at least Carlyle's ambition chimed very obviously with Burke's. The writing of such history must be dramatic, full of hurled kings and noble generals, and the uncertain consequences of human greatness. And no period in English history excited greater dramatic interest than that which Dickens, one of the most fervent of Carlyle's many admirers, termed that 'great seventeenth century'. At the beginning of the 1840s, Carlyle had set about writing what he hoped would be the definitive biography of the Lord Protector. In the end it all became too much, and he settled for a still vast three volume edition of Letters and Speeches of Oliver Cromwell, with elucidations, published in 1845. Carlyle's sympathies were evident, and the Letters and Speeches were a significant moment in the long process of restoring his subject's reputation. Even so in the very last year of the same century, a proposal to erect a statue of Cromwell in Westminster was voted down by mixture of equally appalled Tory and Irish MPs. ${ }^{12}$ Rehabilitating Cromwell would take rather more than three volumes and a bit of sculptured bronze. But it was a start.

As Blair Worden has recently reaffirmed, in many ways so much English intellectual history of the last two hundred years can be written in terms of this defining dispositional dichotomy; between the cavaliers and the round-heads, between those who, to borrow from Sellars and Yeatman's glorious pastiche, 1066 and All Than, might be termed 'Wrong but Wromantic' and those who were 'Right but Repulsive'. ${ }^{13}$ There are of course lots of roundheads and cavaliers ensconced in the historical memory, lots of blank looking puritans staring out of contemporary paintings, and lots of gaily attired cavaliers wearing improbably feathered hats. But few roundheads and few cavaliers are more firmly ensconced than Charles and Cromwell; just as there are few moments in English history more commonly recalled, however hazily, than that which occurred on the morning of January $30^{\text {th }} 1649$. History is all about reputation and recollection; something which was just as readily appreciated in 1649 as it is today. The cultural politics of the Renaissance moved increasingly around respective

\footnotetext{
$10 \quad$ Burke, Reflections, 94.

11 Burke, Reflections, 111, 229, 319

12 In the end it was erected on the lawn outside. It had further been hoped that much of the funding for the statue would be raised by public subscription. It was a vain hope. In the end the Prime Minister Lord Rosebery, an admirer of Carlyle's Cromwell, paid for it himself. Half a century later, Durham University contemplated founding a Cromwell college, in honour of the man who had first established a university in the city. It met with a similarly hostile reception. The name continues to divide. For a commentary on the emergence of a later nineteenth century 'cult' of Cromwell, and more especially Carlyle's role in its shaping, see B.Worden, Roundhead Reputations: The English Civil Wars and the Passions of Posterity, (Penguin, 2001), 215, 254-8, 264-7, 288-93 and 296-304, and also C.Hill, God's Englishman: Oliver Cromwell and the English Revolution, (Penguin, 1972), 257-66.

13 Worden, Reputations, 4-6.
} 
recollections of magisterial reputation; around the practice of what Stephen Greenblatt has termed 'self-fashioning'. ${ }^{14}$ The moment Charles I died, Charles the martyr was born; just as Cromwell the warrior-patriot and defender of liberties was transformed into Cromwell the tyrant and king-killer.

For on that very same January morning, a fourth civil war had broken out. Swords may have been sheathed, for a moment at least. But pens had not. The rapid increase in the number of newspapers, both royalist and parliamentarian, had become a distinguishing feature of London politics during 1648 , and within days of the King's execution underground royalist presses were printing florid accounts of the his 'martyrdom'. A Handkerchief for Loyal Mourners was available as early as the $2^{\text {nd }}$ February. ${ }^{15}$ On the $8^{\text {th }}$, the day of the King's burial, a rather more significant memorial tract appeared on the streets of London. It was entitled Eikon Basilike: the Portraiture of His Sacred Majesty in His Solitudes and Sufferings. Though anonymous there was a clear authorial inference. The Eikon articulated the final thoughts of the martyred King himself, a series of reflections gleaned during the final months of his life, and couched in distinctly familial terms; a strategy which resonated with contemporary sympathisers such as Salmasius and Du Moulin, who cast the regicide as a species of parricide. ${ }^{16}$ Whether or not Charles actually wrote any of the Eikon remains a matter of conjecture. At the restoration the newly appointed bishop of Exeter John Gauden claimed authorship, purporting to have chronicled the King's reflections during these final months. Some later historians have accepted the claim, even if it is founded on nothing more than Gauden's assertion. Others have not. It hardly matters, at least in the context of early 1649. It supposed to be written by the King, and was to be read on these terms. Ten days later it was running to a third edition. In time there would be sixty-nine. 'In a word', Gauden later claimed, 'it was an army, and did vanquish more than any sword could'. ${ }^{17}$

Even the illiterate could be impressed. The frontispiece of the Eikon, with an image of the martyred King kneeling in prayer, his earthly crown at his feet, clutching a crown of thorns, his eyes fixed reverently on the heavenly crown that was to be his, left little to the imagination; or perhaps everything. Charles had not just been executed; he had been crucified. ${ }^{18}$ The same sacral imagery dominated within the text. Charles had indeed been chosen by God, his 'morality crowned with martyrdom', for 'yet hath He graven such characters of divine authority and sacred power upon kings as', the reader was soberly reassured, 'none may without sin seek to blot out'. ${ }^{19} \mathrm{~A}$ king is 'Thy Temple, Thy Priest, Thy sacrifice and Thine altar'. ${ }^{20}$ There were in fact three Charles Stuarts in the Eikon. Alongside Charles the martyr could be found Charles the constitutional monarch, and Charles

14 S.Greenblatt, Renaissance Self-Fashioning: from More to Shakespeare, (Chicago UP, 2005).

15 For discussion of the prevalence of a licensed, but in effect largely uncontrolled, press at the time of the trial and the months which followed, see C.Wedgwood, A King Condemned: The Trial and Execution of Charles I, (IB Tauris, 2012), 124-7, and also 206-7.

16 B.Boehrer, 'Elementary Structures of Kingship: Milton, Regicide and the Family', 23 Milton Studies $1987,102-8$.

$17 \quad$ The Eikon was originally published with its title in Greek, in an attempt to fool the censors. It worked, for a while at least. See here Wedgwood, King, 206-7, and also P.Knachel, 'Introduction' to Eikon Basilike: The Portraiture of His Sacred Majesty in His Solitudes and Sufferings, [hereafter EB], (Cornell UP, 1966), xi, xxvi-xxx.

18 See here R.Helgerson, 'Milton Reads the King's Book: Print, Performance, and the Making of a Bourgeois Idol', 29 Criticism 1987, 9-11, and also S.Zwicker, Lines of Authority: Politics and English Literary Culture, (Cornell UP, 1993), 41-2.

$19 \quad E B, 92,179$.

20 EB, 147. The sheer intensity of the religiosity betraying a 'claim' not merely to 'a divine right to rule, but also a more personal kind of divinity', according to Laura Blair McKnight in 'Crucifixion or Apocalypse', 138. 
the 'pious' and devoted father of the nation. Revisiting medieval ideas of mixed monarchy, the Eikon emphasised Charles's determination 'to restore the laws and liberties of my people' and to govern 'only by such laws as my people, with the House of Peers, have chosen'. ${ }^{21}$ Above all however it emphasised just how much Charles liked to pray, assuming as he did the 'sins of my people'. 'Impute not me with the blood of my subjects', Charles prays in anticipation, 'but wash me with that precious blood which hath been shed for me by my great peacemaker, Jesus Christ'. ${ }^{22}$ Sacrifice must be followed by atonement, and the thousands who purchased copies of the Eikon were seeking precisely that. ${ }^{23}$

Roundhead rebuttal was inevitable. A first anonymous tract entitled Eikon Alethine, concerned primarily with the question of authorship, appeared in August 1649. Rather more significant, certainly more savage, was John Milton's Eikonoclastes, which rolled off the presses two months later. Milton, shortly to be appointed Secretary for Foreign Tongues, in effect chief propagandist for the new English Republic, had already drafted his Tenure of Kings and Magistrates; very probably during the weeks surrounding the King's trial. It appeared a couple of weeks after the Eikon. The Tenure justified the hurling of monarchs in general, Eikonoclastes that of Charles Stuart in particular. The former advanced the idea that the power of 'magistrates is nothing else, but what is only derivative, transferr' $d$ and committed to them in trust from the People, to the Common good of them all'.${ }^{24}$ The latter was an exercise in character-assassination. ${ }^{25}$ The executed King, a bloodthirsty, dissimulating, papist zealot, a 'Tyrant' whose 'deepest policy' had 'bin ever to counterfeit Religion', and had been justly removed by a people chosen by God, as a 'speciall mark of his favour', and with this particular purpose in mind, to defend 'truth and public libertie' against 'suttle dissimulation' ${ }^{26}$ The latter invocation was repeatedly spliced to the larger jurisprudential refutation. God's chosen people had not merely hurled a closet papist and his 'dancing divines'; they had also despatched his 'grinding' prerogative courts and reaffirmed the principles of the 'ancient' constitution, laws 'so ingrav'd in the hearts of our Ancestors, and by them so constantly enjoy'd and claim'd, as it needed not enrouling, ${ }^{27}$

Whilst the 'knowing Christian', and presumably the knowing common lawyer, would not be taken in, the martyr-cult cast in royalist tracts such as the Eikon could too easily 'befool' the 'inconstant, irrational, and Image-doting rabble'.$^{28}$ Accordingly, against the 'quaint Emblems and devices' which characterised such pieces of 'Romish guilded Portrature' Milton invoked the reason of history; to

21 EB, 26, 120. On the consonance of theological and constitutional imagery in the Eikon, see Zwicker, Lines, 37.

$22 \quad \mathrm{~EB}, 123$.

23 Casting the 'same spell', it has been supposed, 'as had Foxe's Book of Martyrs on a previous generation. See Robertson, Brief, 208.

$24 \quad$ M.Dzelzainis (ed) Milton: Political Writings, (Cambridge UP, 1991), 10.

25 Written, it has been suggested, with the 'belligerence of a prosecutor carrying out a savage crossexamination of a deceitful defendant'. See Knachel, 'Introduction', xxiv.

26 J.Milton, Eikonoclastes [hereafter E], in M.Hughes (ed) Complete Prose Works of John Milton, (Yale UP, 1962), 3.348-9. The prevalence of sanguinary imagery in Milton's essay is striking. For a commentary on the deeply personal nature of Milton's attack, see J.Bennett, 'God, Satan, and King Charles: Milton's Royal Portraits', 92 PMLA 1977, 442-3 and 455, stressing the extent to which Milton further insinuates that Charles acted under a Satanic influence. For further commentaries on the broader presentation of Satanism in Milton, see H.Trevor-Roper, Catholics, Anglicans and Puritans, (Secker and Warburg, 1987), 235-40

$27 \quad \mathrm{E}, 3.401-2$.

$28 \quad E, 3.343,601$. 
'cast down' the delusions of 'fansie' and 'imagination' ${ }^{29}$ The more particular history to which Milton sought recourse was the Reformation; a subject which he had first engaged in a 1641 essay on the subject, and in which he had railed against the 'deceitful' counter-reformation settlement instituted by Archbishop William Laud. ${ }^{30}$ Against the 'servile yoak of Liturgie', the 'fantastick dresses' and 'gaudy Copes' and 'dominical Jiggs', and all the 'painted Windows, Miters, Rochets' and altar rails that Laud had reintroduced, Milton championed the plain 'Truth' of the 'Word' that furnishes the 'spirituall words of holy censure' for the 'pulling downe of strong holds, casting down imaginations, and every high thing that exalteth it selfe against the knowledge of God'. ${ }^{31}$

Milton and Gauden of course represent polar positions in the emergent debates which oscillated around the regicide and its consequences. The vast majority of Englishmen and women eschewed such extremes; perhaps not feeling the same kind of passion for either argument, or more commonly, for reasons of expedience, simply preferring to keep their political affinities closer. In time the word 'trimmer' would acquire a pejorative tenor. But in seventeenth century England, many esteemed it to be a mark of simple common sense. The King might have lost the war; but it was far from clear who would win the peace. England in 1650 was a very worried place. Fairfax was said to be a broken man, 'melancholy mad'. ${ }^{32}$ The Engagement Oath stuck in the craw of many gentlemen who were anyway struggling to reconcile themselves to what had happened the previous January, whilst rumours of various Irish, Scottish and continental armies preparing to invade were incessant, as were reports of Leveller uprisings in variously disaffected army units. ${ }^{33}$ In the opinion of many there was only one prospective saviour of a people dangerously close to be being forsaken, Oliver Cromwell.

In was evidently the opinion of Andrew Marvell, whose Horation Ode upon Cromwell's Return from Ireland remains perhaps the most remarkable attempt to achieve some kind of poetic accommodation of an otherwise intractable political dissention. ${ }^{34}$ Blair Worden has suggested that the Ode might indeed be read as precisely such a testament, to the agonies of a disappointed royalist attempting to reconcile himself to the starker realities of life in Cromwellian England. ${ }^{35}$ The

$29 \quad E, 498-9$.

$30 \quad E, 3.535$.

$31 \mathrm{E}, 3.310,358,505,558$. The allusion to the 'casting down' of 'imaginations' refers to Corinthians 10:4-

6. For a commentary on Milton's use of this particular Biblical text, see D.Loewenstein, '"Casting Down Imaginations": Milton as Iconoclast', 31 Criticism 1989, 253-70, and also Zwicker, Lines, 46-9, noting the similar prevalence of metaphors of unmasking.

32 In Worden, 'Politics', 527, and also 528 suggesting that in the eyes of many the act of regicide and the establishment of the republic seemed like an 'act of constitutional rape'.

33 See here J.Scott, 'The English Republican Imagination', in J.Morrill (ed) Revolution and Restoration: England in the 1650s, (Collins and Brown, 1992), 36-9, and S.Kelsey, Inventing a Republic: The Political Culture of the English Commonwealth 1649-1653, (Manchester UP, 1997), 6-7.

$34 \quad$ Perhaps even 'the greatest political poem in the English language', according to Nigel Smith. See his Andrew Marvell: The Chameleon, (Yale UP, 2012), 79-83, further supposing the more particular and immediate influence of contemporary debates regarding the newly imposed Engagement Oath. For a similar assumption in regard to the political ambiguity evident in much of Marvell's poetry at the turn of the 1650s see also D.Norbrook, Writing the English Republic: Poetry, Rhetoric and Politics 1627-1660, (Cambridge UP, 1999), 166, and also 271-4.

35 Worden, 'Politics', 525-6, referring to the 'Horatian transition', and also 533-5 and 539-40 exploring the 'layers' of ambiguity written into the Horatian Ode. The same political journey is traced in Smith, noting the early influence of royalist poets such as Cowley and Lovelace, in time superseded by that of Milton and political reality. See his Marvell, 64-5, 80, 84-6, 106. 
Horatian Ode was of course written in the classical tradition of martial poetry; the protagonists of which were distinguished less by their humanity or sensitivity than by their heroic virtue and ability to win battles. ${ }^{36}$ Similar panegyrics, many written in the same style, were not uncommon. ${ }^{37}$ Marvell would write further in his The First Anniversary in 1654 and then again on Cromwell's death four years later. But these were essentially public poems, written to explore and to acclaim the office of the Lord Protector as much as the man, for which reason they assume a certain intellectual and emotional distance. ${ }^{38}$

The Horatian Ode was different, more evasive, more 'private' as Worden has supposed, but also a poem full of 'actors'; not just about the alternative models of governance, but about the individuals who find themselves, by chance or by will, obliged to govern.$^{39}$ But there is something else that was a bit different about the Horatian Ode, for it is not just about Cromwell, and his 'return from Ireland'. It also about Charles Stuart and what happened on January $30^{\text {th }} 1649$. There are then two, very different, heroes in the Ode. The greater presence is taken by 'restless' Cromwell, the instrument of divine will, the 'force of angry heaven's flame' $(9,26)$; the man who, in a gesture towards the larger constitutional consequences of January 1649 has 'cast the kingdom old/Into another mould' (35-6); and also a 'Caesar', the kind of man who is 'fit for higher trust' in the new, and worryingly unsteady, republic $(80,101)$. The classical allusion was an obvious resource, and commonly assumed in the many and variously cloying panegyrics. ${ }^{40}$ Not everyone was convinced. Lucy Hutchinson scorned 'This Caesar found in our dissembling Age'. A few years later, the Leveller Edward Sexby would condemn the same deceit in regard to the office, and the person, of the Lord Protector; 'a Stately thing/ That confesseth itselfe but the Ape of a King' ${ }^{41}$ But Marvell was clearly more easily reconciled, in large part because he was concerned rather more by pragmatics than by principle. King-less England, as the opening stanzas of the Ode confirmed, needed a Caesar:

Though justice against fate complain,

And plead the ancient Rights in vain:

But those do hold or break

As men are strong or weak. (37-40)

It was again a common perception. Marchamont Nedham said precisely the same in his The Case of the Commonwealth of England Stated, published in the summer of 1650: 'The power of the sword is,

36 For a discussion of this tradition, see Norbrook, Writing, 252-5, noting that it was just as commonly favoured by poets envisaging a 'royal return', and also Kelsey, Inventing, 68-73 and also 212 suggesting that Marvell was 'not so much emulating classicism as rescuing it from Augustan decline.

37 The most renowned, amongst contemporaries certainly, was probably Waller's A Panegyrick to my Lord Protector which appeared in May 1655.

$38 \quad$ Marvell was very evidently more comfortable in the Protectorate than he was in the Commonwealth which preceded it. See here Smith, Marvell, 125-6, 149-52, and also Norbrook, Writing, 243, 250 and also 33941, exploring parallels between the First Anniversary and the Horatian Ode, and also in more general terms S.Zwicker, 'Models of Governance in Marvell's The First Anniversary', 16 Criticism 1974, 1-12.

39 See Worden, 'Politics', 525, and also Norbrook, Writing, 243-4 commenting on Marvell's evasiveness.

40 See here Norbrook, Writing, 228-42, and also 332-7, discussing Milton's Second Defence of the English People, published in 1654, as an expression of 'Roman' republicanism.

$41 \quad$ Norbrook, Writing, 313-6, 324. 
and ever hath been, the foundation of all titles to government' ${ }^{42}$ And so, more famously still, did Thomas Hobbes in his Leviathan published a year later: 'Covenants without the Sword, are but Words, and of no strength to secure a man at all'.$^{43}$ Ultimately Marvell appraised his Cromwell on precisely these terms. The close of the poem leaves the reader in little doubt that England needs not just a Caesar, but a 'power':

But thou, the War's and Fortune's son,

March indefatigably on,

And for the last effect

Still keep thy sword erect

Besides the force it has to fright

The spirits of the shady night,

The same arts that did gain

A power, must it maintain. (113-20)

And there is only one man who can deliver this 'power'.

Charles, to whose fate Marvell turns towards the middle of the Ode, is a very different kind of hero. Like so many of his contemporaries, and so many later commentators, Marvell clearly appreciated the dramatic potential of January $30^{\text {th }} 1649 .{ }^{44}$ The execution of a king, as Cromwell had appreciated, was not the kind of thing that might be done in a 'dark corner'. There would be no hiding the King, dead or alive; a public trial, a public decapitation, even the public display of the body, at St. James for any sufficiently intrigued to pay the small admission fee ${ }^{45}$ Cromwell was persuaded by the idea of a public trial, and a public execution; and what Cromwell preferred matter most. But there were evident risks; for whilst Charles had his failings, it would become apparent that knowing how to die was not one of them. Cromwell might assume the greater presence in the Ode, but it is Charles who gets the best lines. Skipping lightly from Carisbrooke to Whitehall, Marvell relates the tragic events of that so 'memorable hour' (65):

That thence the royal actor borne

The tragic scaffold might adorn:

While round the armed bands

Did clap their bloody hands.

He nothing common did or mean

42 In Worden, 'Politics', 533, suggesting further at 535-9, that writers such as Nedham and indeed Marvel were, as a consequence, drawn towards Machiavellian parallels.

$43 \quad$ T.Hobbes, Leviathan, (Penguin, 1985), 223.

44 On the inherent theatricality of the events, see Worden, 'Politics', 544 and Zwicker, 'Head', 42.

45 Boehrer, 'Structures', 97-8. 
Upon that memorable scene:

But with his keener eye

The axe's edge did try:

Nor called the gods with vulgar spite

To vindicate his helpless right,

But bowed his comely head

Down as upon a bed. (53-64)

These are not, as later commentators have averred, the words of a republican zealot. This is Charles the martyr not Charles the tyrant, a 'royal actor' playing his part to the very end, stealing the scene. His 'right' may have been 'helpless', but the king-less future looks less than hopeful, one of 'forced power', jeering militiamen, and endless wars against the Irish and the Scots. ${ }^{46}$ The term 'comely' was very probably intended to import a particular consonance too. It had been reported that the Earl of Montrose, recently executed following an abortive royalist rebellion in Scotland, had met his fate with a 'comely' dignity. ${ }^{47}$ The idea that it might in the end be Charles who emerges as the real hero of the Horatian Ode resonates with the conclusion that Eikonoclastes might have been Milton's 'most dismal' literary 'defeat' ${ }^{48}$ Republican England preferred poetry to prose; whilst the Eikon went through sixty-nine editions, Eikonoclastes managed just three. And it still seemed to like the idea of kings, especially saintly, martyred ones. ${ }^{49}$ 'This nation', as Lord Broghill observed in 1657, urging Cromwell to accept the crown, 'loves a monarchy'..$^{50}$ The decision to execute the King in public proved to be 'disastrous'; as disastrous indeed as the decision to try him in public. ${ }^{51}$

\section{Doing His Work}

Early modern English history has long attracted the attention of modern British dramatists. The events of the mid-seventeenth century, more particularly the rise of the Levellers and similar radical movements, attracted a generation of younger playwrights writing during the closing decades of the last century with the intention of reinvesting a distinctive left-wing socialist theatre. It is to this generation that Howard Brenton belongs, alongside the likes of David Edgar, David Hare, with whom he wrote a number of plays, and Caryl Churchill. ${ }^{52}$ In plays such as Vinegar Tom and Light Shining in

46 See Norbrook', Writing, 267, commenting on the role of the jeering soldiers at the moment of the king's 'beautiful end', thus conjuring an imagery that 'grotesquely breaks the frame of art'.

$47 \quad$ See Worden, 'Politics', 543.

48 See Boehrer, 'Structures', 99 and also 115 concluding that 'the failure of Eikonoclastes was principally a failure of rhetoric', and also McKnight, 'Crucifixion or Apocalypse', at 140, reaching much the same conclusion.

$49 \quad$ The young Samuel Pepys might be counted amongst the exceptions however. He attended the execution, aged just 15, subsequently declaring that if he had to preach on the subject he would take as his text 'And so the wicked shall rot'. See Wedgwood, King, 197.

$50 \quad$ In Fraser, Cromwell, 607.

51 See Robertson, Brief, 198.

52 See here R.Boon, 'Retreating to the Future: Brenton in the Eighties', 33 Modern Drama 1990, 33, and also M.Billington, State of the Nation: British Theatre Since 1945, (Faber and Faber, 2007), 215-22 and 255, discussing Brenton's place at the head of this 'new gang', amongst whom could also be counted, perhaps most 
Buckinghamshire, Churchill further added a gender dimension to the dramatic reinvestment of seventeenth century English history; thus fashioning a more particular genre of 'witchcraft plays' which would in turn be developed further by the likes of Sarah Daniels, Bryony Lavery and Rona Munro. ${ }^{53}$ In relative terms, however, rather less dramatic attention has been paid to the higher political consequences of the English revolution; until now at least. It is certainly no surprise that Brenton should have chosen to embrace the possibility. His reputation as 'chief chronicler of the nation's past' is little contested; possessed of a peculiar 'genius for turning the history of ideas into powerful drama'; English theatre's 'history man', according to Michael Billington. ${ }^{54}$

What kind of 'history man' is of course another matter, for writing history is never simply a matter of chronicling things that happened. Critics have certainly tended to prefer a revisionist Brenton, someone who 'deconstructs history', who is attracted to moments of 'rupture'. ${ }^{55}$ And there are of course few more such dramatic moments than late morning on January $30^{\text {th }} 1649$. And yet, whilst there is much about the events of late 1648 and early 1649 which seems sudden, not least the idea of bringing the King to trial, there is also and always a longer story. Radical writing, as David Edgar has suggested, is no less radical for being written as part of a 'grand narrative'.$^{56}$ There is here a particular context. 55 Days is a sequel. Two years earlier, in July 2010, Brenton's Ann Boleyn was first performed at Shakespeare's Globe Theatre. It and 55 Days are two parts of a larger dramatic chronicle, investigating the consequences of the English reformation. The strategy is of course intrinsically Whiggish, making the 'moment' of January $30^{\text {th }} 1649$ the product of a much longer imagining; much longer than fifty-five days. The English civil war, as Brenton appreciates, was 'a long time stirred' ${ }^{57}$ England decapitated its king because it had never properly reconciled itself to the consequences of what an earlier Cromwell had chosen to do..$^{58}$ The Whiggish alternative supposes that January $30^{\text {th }} 1649$ happened because Archbishop Laud had refurbished too many of the altarrails and rood-screens which Thomas Cromwell's commissioners had torn down a century before. ${ }^{59}$

The role of Brenton's curiously comic King James I in Ann Boleyn reinforces this historical and thematic continuity. James does not occupy the same elevated status in the historical memory as his son; perhaps because he never went to war with his Parliament and he died in his bed. There were certainly moments of high constitutional tension, most famously apparent in a series of running

obviously, the likes of David Hare, Stephen Polliakoff and Edward Bond, and also D.Edgar, State of Play: Playwrights on Playwriting, (Faber and Faber, 1999), 7-14. For a more cautious commentary on the identification of 'generations' of dramatists, see J.Reinelt, 'Selective Affinities: British Playwrights at Work', 50 Modern Drama 2007, 307-9.

$53 \quad$ In plays such as Byrthrite, Witchcraze and The Last Witch respectively.

$54 \quad$ See http://www.theartsdesk.com/theatre/55-days-hampstead-theatre;

http://www.timeout.com/london/theatre/55-days; httop://www.theguardian.com/stage/2012/oct/25/55days-review.

55 M.Zelenak, 'The Politics of History: Howard Brenton's Adaptations', 18 Theatre 1986, 55. A similar conclusion is ventured by Michael Patterson in his Strategies of Political Theatre, (Cambridge UP, 2003), at 100.

56 Edgar is making reference to a subsequent part of the same 'narrative'. See his comments in State of Play, at 7-8.

$57 \quad$ A point noted by Brenton in '55 Days'.

58 The two were very distantly related, Oliver being descended from Thomas's sister, Katherine.

Christopher Hill speculates that Oliver's reputation as an iconoclast may owe something to a broader popular confusion regarding the two Cromwells. See his Englishman, 262. For the revisionist argument see Wedgwood, King, 12.

59 See G.Burgess, Absolute Monarchy and the Stuart Constitution, (Yale UP, 1996), 101-3. 
disputes with his Lord Chief Justice, Sir Edward Coke, over the balance of sovereign and judicial discretion. ${ }^{60}$ The Whig narrative, being intrinsically constitutional, invariably places lots of discontented common lawyers alongside their discontented puritan compatriots during the increasingly fraught 1630 s and 1640 s. And it is certainly true that questions of jurisprudence loomed large in contemporary revolutionary debate. ${ }^{61}$ The civil wars, in this narrative, become wars of liberation, the execution of the King the moment when the essential principles of English constitutionalism were 'confirmed', the sovereignty of Parliament, the independence of the judiciary, the rule of law. ${ }^{62}$ Whig historiography thus traces the fall of the son to the sins of the father; a narrative which is further coloured by the famous declamation that the distinctly un'wromantic' James was the 'wisest fool in Christendom'. There is something of this historiography in Brenton's James. But there is also the appreciation that the same James was perhaps a little wiser and a little less foolish than Whig historians have liked to suppose, not least in his closer appreciation of the problems which afflicted post-Reformation England. ${ }^{63}$

55 Days is then about a far longer historical moment than a mere seven weeks and a day; no matter how momentous that day. The grander constitutional visions so firmly embedded within Whig historiography repeatedly assume centre stage in Brenton's chronicle; quite literally in Act 1 Scene 8 which revisits the Whitehall debates of $13^{\text {th }}$ and $14^{\text {th }}$ December 1648 . Whilst the debates were intended to focus on the proposal for religious toleration included in the recent Leveller Agreement of the People, such consideration could not be detached from broader questions of government, of liberty of conscience, and the relation of 'the restrictive power and the compulsive power' ${ }^{64}$ And it is towards these that Brenton directs his audience's attention. The more esoteric theological questions are divested. Instead, Brenton takes the opportunity to establish political parameters; between the conservative Army officers and their more radical Leveller antagonists. Not all radicals thought the same, of course. Colonel Pride adopts a grimly prosaic attitude to the question of what to do with the King; 'Drag' him 'from his castle, and beat him to death' (45). A more considered radicalism finds a voice in John Lilburne, the author of the Agreement. It has been suggested that Lilburne is the real 'hero' of Brenton's play, perhaps indeed articulating the voice of his creator; a perception which led one reviewer to suppose that whilst the play was undoubtedly 'gripping' its

60 See here G.Burgess, The Politics of the Ancient Constitution: an Introduction to English Political Thought 1603-1642, (Macmillan, 1992), 21-27, 72-8, and also Absolute Monarchy, 102-6, 156-9, 184-208.

61 On the centrality of law and constitution in the Whig narrative, see Burgess, Absolute Monarchy, 2-3, 13. On the parallel dynamics of theology and law, see Woodhouse's Introduction to the Putney and Whitehall Army debates in Puritanism and Liberty: Being the Army Debates 1647-49 from the Clarke Manuscripts, (Dent, 1986), 14.

62 Albert Kiralfy famously concluded that it was the 'common law' which 'forged the axe which beheaded Charles I'. See his Potter's Introduction to English Law and its Institutions, (Sweet and Maxwell, 1958), 43. For accounts of these disputes see Robertson, Brief, 23-6, 148-9, suggesting the extent to which the final charge which was laid against Charles in January 1649 owed much to the arguments ventured by Coke against prerogative jurisdiction, and also 355-6 citing the similar conclusion of the great Whig historian GM Trevelyan in his England under the Stuarts, published in 1915: 'Never perhaps in any century have such rapid advances been made towards freedom'.

63 See here Helgerson, 'Milton', 3-7, noting a collateral consequence of James's determination to reform the reform; the commissioning of an Authorized Version of the Bible.

64 Woodhouse, Puritanism, 151. 
author was evidently 'too much on the rebel's side' ${ }^{65}$ Perhaps; but then striking political balances has never really been Brenton's thing.

Lilburne's principle antagonist is Cromwell's son-in-law Henry Ireton, a common lawyer by training who had served as a parliamentarian general during the war. Ireton has little patience with Lilburne and his 'ragbag of followers' (49). In one sense Lilburne and Ireton have much in common; both claim to be arguing the case for an English constitution. It is the interpretation of this constitution which divides. Ireton presumes to be arguing for the 'ancient' constitution, where power is balanced between Parliament and King. ${ }^{66}$ Cromwell will appeal to the same kind of 'settlement' in his later, imagined, conversation with Charles; though ever the pragmatist he is not so inclined to couch his appeal in the same species of jurisprudential mysticism. If Charles agrees to be a 'constitutional monarch', Cromwell avers, he can at least save his neck. Charles however, by then relishing the idea of martyrdom, dismisses the idea with the pertinent question 'what newfangled thing is that?' (88)

The idea of restraining Parliament is similarly uncertain, as Ireton senses. There must be such 'restraints' because 'Rights must be protected' (45). When pressed on what he means by 'restraints', Ireton seeks recourse to the language of 'Checks and balances', implying that a purge might be justified on these terms (46). As a consequence it is Ireton whom the Presbyterian William Prynne holds responsible for the 'rape' of Parliament on December $6^{\text {th }}(18)$. Lilburne likewise holds Ireton responsible for the evolving events of late 1648 , rejecting his interpretation of constitutional propriety. 'No man', he advises when asked whether the army should support a purge, 'should obey an order he thinks unjust' (15). Parliament is inviolable. There should be 'no other power in the land but Parliament'. Mindful no doubt of Ireton's famous injunction at Putney, that 'no person hath a right to' partake of government 'that hath not a fixed interest in this kingdom' Lilburne suggests that Ireton's idea of 'rights' is limited to the 'rights of landowners' (45). ${ }^{67}$ Ultimately however, as Cromwell intercedes, it is about 'stability'. The constitution exists not to facilitate democracy or equality, but to ensure the stability of the nation; for which reason the 'extremists' must be 'cast out' $^{\prime}(48){ }^{68}$

The same arguments in regard to constitutional propriety and its interpretation animate the prospective trial of the King; 'that great work', as Cromwell was fond of calling it. ${ }^{69}$ At the Whitehall debate Harrison supposes that the King might be brought 'to justice, under the law'. Not everyone is convinced. And when evidence is uncovered of Charles's negotiations with Ormonde it still remains

65 http://www.timeout.com/london/theatre/55-days.

66 For a commentary on the contemporary 'politics' of the 'ancient' constitution, and more especially the place of 'balance', see Burgess, Constitution, 3-4, and also D.Smith Constitutional Royalism and the Search for Settlement 1640-1649, (Cambridge UP, 1994), 19-20, 62-4, 189, emphasising the extent to which moderate 'constitutional royalists' could be found subscribing to much the same idea of an 'ancient constitution'.

$67 \quad$ The question of property loomed large at Putney, and was the subject of a renowned, and fierce, argument between Ireton and the radicals led by Colonel Rainborough, in whose opinion property law was the 'most tyrannical law under heaven'. Ireton repeatedly confirmed that he 'would have an eye to property', for 'The law of God doth not give me property, nor the law of Nature, but property is of human constitution'. The Leveller argument, to the contrary, was that property was given by God to be held in 'common'. See Woodhouse, Puritanism, 54, 57-61 and 69.

68 Such a perspective resonates with the supposition, advanced by the likes of Glenn Burgess, that the ancient constitution was really 'a model of legalism rather than constitutionalism'. See Burgess, Absolute Monarchy, 146-7, and also Smith, Royalism, 178-9, reaching much the same conclusion.

$69 \quad$ Robertson, Brief, 151. 
uncertain as to whether a king can commit 'treason against himself'. It is, as Ireton concedes, 'the conundrum of our time' (51). Harrison has a simple solution to such concerns. If the common law does not accommodate such a charge, then they should simply 'make a new law' (46). ${ }^{70}$ Ireton is similarly adamant that there must be the pretence at least of 'a legal process', even if he is rather less keen on the idea that they might, if necessary, just invent a new law, and when he is found 'guilty', as must be the case, he can then be forced to 'come to an agreement'; a supposition that informed the Remonstrance which Ireton had drawn up a few weeks earlier (46-7). ${ }^{71}$ Inevitably, after the customary squabbling everyone defers to Cromwell, who silently nods his agreement. ${ }^{72}$ And so the King will be tried before a court established at Westminster. It is 'decided', no matter how strongly the radicals protest (48). Lilburne remains opposed to the trial throughout the second Act precisely because it is premised on the authority of a 'purged Parliament' (77). ${ }^{73}$ But it is not Lilburne's opinion that matters; it is Cromwell's. ${ }^{74}$

These constitutional questions quite literally assume centre-stage during the second Act of the play; as for the same reason do the two leading lawyers, John Cooke, who served as chief prosecutor at the King's trial, and the Lord President of the Court, John Bradshaw. ${ }^{75}$ The second Act opens with Cromwell and Bradshaw inviting Cooke to serve as Solicitor-General. Cromwell admires Cooke, as the man who defended Lilburne; though, with typical bluntness, he further admits that pretty much every other lawyer has run away. ${ }^{76}$ The most striking aspect of this scene however is the intense religiosity, the sense of calling which each shares. When in the following scene Fairfax expresses his disdain for men of such 'low' birth, Cromwell responds simply; they 'are doing His work upon Earth' (63). It is enough. England, fallen and 'ripped to bits', must be remade 'for ever' (64-5). They are not

70 An attitude which leads Wedgwood to suppose that he is something of a 'fanatic'. See King, 26.

71 For the idea that Ireton was the most urgent advocate of a public trial, see Robertson, Brief, 134. It was Ireton who found and then persuaded both Bradshaw and Cooke to assume the leading legal roles in proceedings.

72 The same debate, regarding what to do about the King, had generated a similar amount of heat at Putney the year before; so much heat indeed that the note-taking had to be stopped. It is this note-taking which has of course, in the form of the Clarke MSS, proved to be such a rich resource for later historians.

73 On Lilburne's consistent objection to the trial see Wedgwood, King, 72-4. Aside from Lord Grey other significant 'parliamentarian' opponents included Prynne and Algernon Sidney, whose exchange with Cromwell on the subject is renowned. 'First', Sidney observed, 'the King can be tried by no court; secondly, no man can be tried by this court'. To which Cromwell is recorded as having replied 'I tell you, we will cut off his head with the Crown upon it'. In Robertson, Brief, 139.

74 The newly purged Parliament dutifully passed a facilitating Act to Establish the High Court of Justice on $6^{\text {th }}$ January, the preamble to which confirmed that 'Whereas it is notorious that Charles Stuart, the now King of England, has had a wicked design totally to subvert the ancient and fundamental laws and liberties of the nation, and in their place to introduce an arbitrary and tyrannical government'.

$75 \quad$ Cooke has generally enjoyed a rather disparaging reputation down the centuries; perhaps because the history of the King's trial has been more commonly written by historians hostile to the regicide. Wedgwood was clearly discomforted by his 'ferocious zeal'. See her King, 114 . For an alternative view see Robertson, Brief, commending at 1 the 'the bravest of all barristers'.

76 Cooke was appointed following the last minute defection of the Attorney-General Anthony Steele, who pleaded ill-health. The nomination and attendance of those appointed as Commissioners was similarly affected. The vast majority of the 135 nominated Commissioners were drawn from the massed ranks of common law MPs. Roughly half attended the trial. Sixty-eight attended the first day of the trial, and the average daily attendance was around 60. In the end 59 signed the death-warrant. Amongst the most notable of the serial absenters was Fairfax, Cromwell's close friend Oliver St John, and Philip Skippon, a leading Parliamentary general who commanded the London militia. For commentaries here see Royle, War, 491-2, Wedgwood, King, 95-6, 108, and Robertson, Brief, 9-12, 144-5. 
just trying a king; they are securing the redemption of a 'chosen' people. And it was for this reason that the 'tryal' of the king, as Milton later confirmed, had to be 'faire and op' $n$ ', in full view of the broader Christian world. ${ }^{77}$

It was not however easy. The decision to stage a public trial imports an obvious risk; that the scene is likely to be stolen by the best actor. ${ }^{78}$ And it quickly becomes apparent that the best actor in Westminster Hall in early January 1649 is the accused, 'Charles Stuart, King of England' (68). Indeed, Brenton has subsequently confirmed that what attracted him to the idea of writing a play about the events of late 1648 and early 1649 was an initial reading of the trial transcripts and more particularly the 'eerily graceful lines' which were ascribed to the King. ${ }^{79}$ As Colonel Harrison admits, having witnessed the King's performance on the first day of his trial, 'The public have never heard his voice before. Now they find that he speaks like an angel' (71). Ireton reaches the same conclusion: 'We have been ambushed. The King's sense of law is better than we thought. And his sense of expression' (72). And it is not simply a matter of poetry; there is theatricality too. Brenton incorporates a number of happenings familiar from these transcripts, including the dramatic moment when Charles tapped Cooke's shoulder with his cane as the charges were being read out. The top of the cane fell off and, when no one else rushed to pick it up, Charles was obliged to do so himself. ${ }^{80}$ It is, despite the apparent indignity, another moment that Charles steals; everyone 'gasps' and the King on returning to his chair 'looks about with disdain'. 'I did not know the man was a play actor', Cromwell observes with a begrudging admiration; to which Ireton mutters in return 'We closed the theatres, we will close him' (68).The prose will, in the end, overcome the poetry. Ireton suggests that they abandon a public trial, and continue 'in secret' (71). It is the lawyers, Cooke and Bradshaw, who protest: 'Justice must be seen to be done' $(71) .{ }^{81}$

The charges duly read, Charles's primary strategy, as the same transcripts confirm, was to question the jurisdiction of the Court. ${ }^{82}$ 'I would know by what power I am called here', he immediately responds, waving away Cooke's attempt to interject, 'let me know by what lawful authority I am seated here' (69). Rather than simply asserting their jurisdiction and moving on, Bradshaw and Cooke allow themselves to get distracted, and increasingly frustrated. They needed the King to plead to the charge. If he did not then his guilt would be presumed, pro confesso; as the common law determined in cases of alleged treason. And if this was the case the grander plans to parade a string of witnesses all evidencing the King's guilt would be thwarted. ${ }^{83}$ But Charles refused. Once again, it seemed, the King had outmanoeuvred his prosecutors. Bradshaw's response is to assert that the accused has been 'brought here in the name of the people of England, of whom you are elected

77 See Political Writings, 33, and also Wedgwood, King, 93.

78 And the best dressed actor. Charles had chosen his apparel carefully, clothed in black, the Order of the Star of the Garter prominent on his cloak and the bejewelled St George hanging from his neck on the order's blue ribbon.

$79 \quad$ '55 Days: Will Mortimer interviews Howard Brenton', http://www.hampsteadtheatre.com/news/2012/october/55-days-will-mortimer-interview. $80 \quad$ For commentaries on this event see Hoyle, War, 494, Wedgwood, King, 127-8, and Robertson, Brief, 17, 154-5.

81 An opinion they had both strongly argued during the various debates in late autumn 1648 . See Robertson, Brief, 146-7

82 In his recent account of the trial, Geoffrey Robertson refers to this as the 'King's gambit'. See his Brief, 6 and $155-8$.

83 In the end the witnesses, thirty-three in total, were called anyway. See Robertson, Brief, 171-3, and 188-90 noting that the principle of pro confesso would not be abrogated until 1827. 
King, to answer them'. The argument, which resonated with nascent ideas of contractarian sovereignty, would have been familiar to readers of Milton and had been recommended by Cromwell at Putney, 'the King is King by contract' ${ }^{84}$ But it would still have seemed somewhat novel, and to many common lawyers both inside and outside Westminster Hall rather discomforting too; not least because of the uncertain consequences which might flow from any notional breach of trust. ${ }^{85}$ Charles is contemptuous: 'Elected? England was never an elective kingdom. It is an hereditary kingdom and has been for a thousand years' (70). Bradshaw would cling to the same argument throughout the trial, citing it his final judgment. ${ }^{86}$ And Charles would dismiss it with the same disdain, consistently demanding to be shown any 'legal warranty by the Word of God, the Scriptures, or the constitution of the Kingdom'. By now even Cromwell is troubled, and no longer prepared to leave matters to a providential throw of the 'dice', decides it is time to put a stop to matters, and the first trial scene is brought to a close $(66,70) .{ }^{87}$

Whilst Hugh Peter commends 'the more glorious beginning of the work', the Army leaders and the lawyers hurriedly convene to assess the damage and try to chart a new course. ${ }^{88}$ But, as Cooke admits, 'We sail in uncharted waters' (73). Bradshaw agrees. Whilst tyrants have been removed by force before, and he cites Richard III as the prime example, 'never' before has an English king been removed by 'law' (73). Whilst Harrison and Ireton continue to argue the case for just making a 'new' law, Cooke is adamant that they must continue to 'act within the established common law' (73). As contemporary accounts confirm, here Cooke argued hard the distinction between the office and the person of the king; such that the person of a king might always be held accountable for tyrannical acts, regardless of whether his office might or might not be held inviolable. ${ }^{89}$ Otherwise, as Speaker Lenthall confirms, the 'execution will be seen to be unlawful' and all credibility lost (73). It is Cromwell who concludes that they should simply carry on, advising the King that if he continues to refuse to plead, and thereby acknowledge the jurisdiction of the court, a plea will be entered for him. That way they should still be able to get it all done in time for an execution by the end of the week. Cooke demurs at the presumption. But there is no question, at least not in Cromwell's mind: 'We will get there in the end. Find him guilty, within the law' (75). ${ }^{90}$

As the court reassembles the same question dominates. 'A king', the King declares, 'cannot be tried by any superior jurisdiction on earth' (79). Neither can he be tried by his peers, as is the right of any

84 See J.Somerville, 'Oliver Cromwell and English Political Thought', in J.Morrill, Oliver Cromwell and the English Revolution, (Longman, 1990), 237.

85 See here Robertson, Brief, 125 and also 136 suggesting that the original idea, articulated in the draft charge, that the King was somehow guilty for breaching his 'trust', was the 'sort of argument that might pass muster in a tavern, but not in a criminal court'.

86 See here Robertson, Brief, 184-5.

87 As Wedgwood concludes, it very quickly became apparent that the 'progress of the trial was little short of disastrous'. See King, 146, and for a similar conclusion, Hoyle, War, 494-6.

$88 \quad$ There is no record of what happened at this session, for which reason Brenton can only surmise. For further conjectures, see Royle, War, 495-6 and Robertson, Brief, 160.

89 See Robertson, Brief, 15-16, suggesting that Cooke was reaching towards the modern doctrine of 'command responsibility'.

$90 \quad$ Although Brenton has Cooke demur at the presumption of guilt, Robertson notes subsequent testimony which suggests otherwise; that the Solicitor-General had assured a young George Starkey that 'The King must die, and monarchy die with him'. The testimony was produced at Cooke's later trial in 1660 . See Robertson, Brief, 176, 312, 319-20. 
Englishman; quite simply because the King has no 'peers' ${ }^{91}$ Bradshaw again struggles to assert himself, earning ridicule when he suggests that the King might be 'charged as a high delinquent' (79). Charles gets all the laughs, and when he again challenges the assertion that the Commons might be considered a 'court of judicature', there are cries of 'Justice! The King!' heard in the gallery. Another 'crack' in the case, as Ireton mutters to Cromwell (79-80). Proceedings are once again brought to a hurried close and the King is hustled away. Further discussions follow, at which it becomes apparent that Cromwell is losing patience, with the lawyers in particular. Bradshaw confesses that Charles is indeed right. The Commons is not a court of 'judicature'. 'What', an exasperated Cromwell responds, 'in the bowels of Christ, is that!' If the Commons is not now a court of law it can be made one 'By Act of Parliament. In the morning' (81). Bradshaw and Cooke immediately consult on the possibility of a Chancery ordinance. Cromwell however is not inclined to waste any more time on 'quaint' legal devices. It is the 'future ground of England' that concerns him, the idea of making 'Parliament the most powerful thing in the land' (81). What matters is fulfilling the 'Lord God Almighty's purpose', not ferreting out common law precedents (82). ${ }^{92}$

The final trial scene, which takes place immediately after the imagined conversation between Charles and Cromwell, is shorter. The court reconvenes and Cooke reads out the opinion of the court, that 'the charge is true, as clear as crystal and as the sun that shines at noon', that Charles has been found 'guilty of a wicked design to introduce a tyrannical government, with himself at the head, in defiance of Parliament and its authority' (90). In response Charles, as has been predicted, again challenges the jurisdiction of the court. On this occasion however he is silenced. Led by Cromwell, who senses an initial reluctance, the commissioners step forward in turn and confirm Cooke's opinion. It is, Cromwell mutters, a 'cruel necessity' (91). ${ }^{93}$ It is left to Cooke to confirm the sentence, that 'Charles Stuart shall be put to death, by severing his head from his body' (92). ${ }^{94}$

\section{Uneasy Heads}

The trial scenes reinforce a critical dramatic insight; that the larger questions of constitutional and religious settlement are calibrated by particularity, by particular human actors saying particular things and making particular choices at particular moments in history. Thirty years ago, Brenton identified himself with a species of 'new Jacobean' playwright in part because he was writing about

91 This particular defence was recommended by Sir Orlando Bridgman, who served as one of Charles's principle legal advisers during the trial. Bridgman would subsequently return to centre-stage at the Restoration when he presided over the trial of the remaining regicides. See Wedgwood, King, 32, and Robertson, Brief, 123, 129.

92 It was, as the radical preacher Hugh Peter confirmed outside Westminster, God's 'work' and it was 'glorious'. See Wedgwood, King, 134, and also Robertson, Brief, 71-2, contemplating the extent to which there was a broader discontent with the devices of the common law in early seventeenth century England. Cromwell had read law at Cambridge, and yet his dismissal of legal devices is characteristic. For a commentary on this seeming ambiguity, see J.Morrill, 'The making of Oliver Cromwell' in Morrill, Cromwell, 23-4.

93 The attribution of this particular phrase remains uncertain. It was first recorded by Alexander Pope, and was originally supposed to have been muttered by Cromwell on visiting the corpse of the King in the very early hours of the morning after his execution. There is no credible evidence that Cromwell did visit the corpse, still less make any comment. There again there is no hard evidence that he did not. See Robertson, Brief, 201, and Fraser, Cromwell, 293-4.

94 The sentence was actually read out by Bradshaw, as President of the Court. He sought extensive recourse to Bracton, but also emphasised once again the rather more novel idea that the Crown was held in 'trust', as a 'contract and a bargain between the King and his people', and that this contract had been breached. See here Wedgwood, King, 159-61. 
the human experience of 'power and suffering'. ${ }^{95}$ The same aspiration underpins 55 Days. It is after all a drama, in much the same way indeed as Marvell's Horation Ode can be read as a piece of verse drama. Marvell 'fashioned' a particular moment, a drama populated by particular characters, a particular Cromwell and particular Charles; as indeed did Milton. And they all suffer in different ways, sometimes majestically, sometimes more prosaically. Brenton's 'great' Fairfax is a broken man, so laid low by the 'burden' of office that he now resembles 'a walkin' skeleton' (13). The very first scene of 55 Days reinforces the same juxtaposition, three 'bloody freezing' parliamentarian soldiers huddled over a fire contemplating what it means to be part of 'God's army, fighting for a new Jerusalem'(7-8). A few lines later, a young trooper wonders if the army really can purge a Parliament it has 'sworn to protect'. His older, more pragmatic companion in arms replies simply 'It's called politics boy' (12). The same essential tensions recur time and again in 55 Days, between the poetry and the prose, the cavalier and the roundhead.

Ultimately however 55 Days is about Charles and Cromwell, their very different perceptions and experiences of magistracy, and the conversation which Brenton, with the facility of dramatic license, fashions between them. This latter invention caused some critical consternation. ${ }^{96}$ There were later rumours, chiefly propagated after the Restoration by royalist polemicists such as Clement Walker, that the King had indeed been approached, sometime around the $28^{\text {th }}$ of January, with the offer of a conditional reprieve. But the reports did not suppose that Cromwell had carried the offer in person, nor indeed is there any credible evidence that anyone else carried such an offer. ${ }^{97}$ Charles and Cromwell did meet in person, perhaps most notably in July 1647 at Childerley, shortly after Cornet Joyce had famously seized the King on behalf of the Army at Holdenby House. Cromwell was part of a deputation led by Fairfax and was, with Ireton, recorded as having behaved 'with good manner' to the King. ${ }^{98}$ Interestingly Brenton has Charles ask, on arriving for the first day of his trial, 'Which one is Master Cromwell?' (67); a tactic which presumes that Cromwell had made little or no impression at Childerley. It is certainly true that they never met as Brenton has them meet, in close and earnest conversation. The meeting, which is set at the Cotton house, where the King was held during his trial, allows Brenton to crystallise and contrast two very different men and two very different perceptions of magistracy. ${ }^{99}$ Most importantly however it impresses what is perhaps Brenton's defining insinuation; that the vision cannot be distinguished from the prejudices of the visionary.

Brenton creates his Charles and his Cromwell, and creates them human, for which reason they are supposed to be confused and conflicted and frustrated; 'one fighting for a future he struggled to imagine, the other for a past that was a fantasy'. ${ }^{100}$ It is reasonable to suppose that, in the matter of their respective politics at least, Brenton feels rather greater affinity with Cromwell than with

\footnotetext{
95 Brenton, 'Red Theatre', 198.

96 There again Quentin Letts in the Daily Mail recommended the play nevertheless for being 'balanced, serious' and 'interesting'. http://www.dailymail.co.uk/tvshowbiz/article-2223339/55-Days-theatre-review. 97 See here Wedgwood, King, 169 and 190, evidently sceptical of the idea.

98 A. Fraser, Cromwell: Our Chief of Men, (Methuen, 1985), 196, J.Bowle, Charles I, (Weidenfeld and Nicolson, 1975), 293-4, and Royle, Civil War: The Wars of the Three Kingdoms 1638-1660, (Abacus, 2004), 4001.

$99 \quad$ Charles resided at the Cotton House during his trial, and was transported daily to Westminster by barge. It was convenient. Sir Robert Cotton, who had died in 1631, was famous as a great collector and early member of the Society of Antiquarians. His vast collection, including the famed Cotton Library, was later donated to the British Library.

100 Brenton, '55 Days'.
} 
Charles. As a dramatist however there is, rather obviously, something about Charles to which Brenton is peculiarly drawn; the king who could indeed conjure such 'eerily graceful lines', 'slippery' maybe, but also a consummate actor. ${ }^{101}$ Charles first appears in the play to a chorus of Richmond's admiring 'Oh played, played Your Majesty' (22). Charles has just won a game of bowls. But it is the playing which has impressed, and Brenton has chosen his words carefully. Later in the same conversation, Charles reassures Richmond that, despite the assurances he has given the Presbyterians regarding the abolition of bishops, he has no intention of keeping his word (23-4). Later still it becomes apparent that Charles is negotiating with the Duke of Ormonde for the raising of a new Royalist army in Ireland; evidence in Ireton's opinion that the King is a 'liar'. Cromwell prefers a different language and a different judgment. The evidence simply confirms that Charles is a 'political man', doing what kings do (51). And as we have already noted Charles consistently steals the trial scenes during the second Act. Time and again he bests the lawyers Bradshaw and Cooke, leading to a series of hurried adjournments. It is interesting that when he and Cromwell finally meet, at the Cotton house, Charles is seated 'reading law books' (84). But it is not of course his knowledge of jurisprudence which really matters. It is his ability to act.

Brenton thus fashions his Charles as an actor-king in much the same way that Shakespeare fashioned his Henry V or Richard II. Such a fashioning was certainly appreciated by reviewers. In the original production Charles was played by Mark Gatiss, in the admiring opinion of one critic as a 'lanky, vicious fop with perfect comic timing' ${ }^{102}$ From a slightly different angle, Michael Billington appreciated the capacity of Gatiss to induce the 'sympathy' of the audience, whilst reinforcing 'the Shakespearian point about the essential solitude of kingship'. ${ }^{103}$ Charles Spencer in the Telegraph ventured a different, but no less perceptive, parallel; with the dramatic Charles brought to poetic life in Marvell's Ode. ${ }^{104}$ There is much else about Brenton's Charles which is familiar, aside from the foppishness and the slipperiness. There is, for a start, the defining delusion of Stuart monarchism, that the King has been anointed by 'divine right', that he is 'so much more' than a mere 'man in the eye of God' (39). Such a supposition had found famous expression in a succession of treatises penned by Charles's father, King James I. Monarchy, as readers of The Trew Law of Free Monarchies would have discovered, 'is the trew patterne of divinitie', for 'Kings are called Gods' because 'they sit upon God his throne in the earth'. ${ }^{105}$

The extent to which Charles is wedded to this perception of kingship is evident during his conversation with Cromwell at the Cotton house. Cromwell's proposition, that there might be a constitutional 'settlement' in which the King would become 'the figurehead of the nation' is countered by a simple referent to the 'oil' (88). To Cromwell it is just a 'dribble of sticky stuff'. But to Charles it is everything, evidence of his quasi-divine authority, and, in words which resonate very obviously with those articulated by Shakespeare's Richard II at the moment of his deposition,

\footnotetext{
101 For Brenton's observations see '55 Days: Will Mortimer interviews Howard Brenton',
} http://www.hampsteadtheatre.com/news/2012/october/55-days-will-mortimer-interview. The perception of Charles as 'slippery' resonates with Wedgwood's supposition that he was 'a brave man, but he was also secretive and devious'. See her King, at 11.

102 http://www.timeout.com/london/theatre/55-days.

103 See http://www.theguardian.com/state/2012/oct/25/55-days-review.

104 http://telegraph.co.uk/culture/theatre-reviews/9633745/55/55-days-Hampstead.

105 J.Somerville (ed) King James VI and I: Political Writings, (Cambridge UP, 1994), 64. For commentaries on James's idea of kingship, see J.Somerville, Politics and Ideology in England 1603-1640, (Longman, 1986), 912, 23-36, and Burgess, Constitution, 143-56. 
Charles confirms his opinion that 'It is the power. It is on me. Not all the water in the sea can wash it away' (88). ${ }^{106}$ It is for this reason that Charles cannot countenance the idea of being a 'constitutional monarch'. Monarchs are not defined by constitutions. They are chosen and invested by God.

The idea that the English civil wars were primarily 'wars of religion' has become a centrepiece of modern historical scholarship; and Brenton clearly approves. ${ }^{107}$ What has aligned the various 'parliamentarian' factions, as an early exchange between Prynne and Harrison confirms, is a shared distaste for 'bishops'. Charles, as Harrison confirms, is 'damn well near a papist' (18-19). As ever with Charles it is as much a matter of perception, of what he seems to be 'near'. But perception, in late 1648 , was everything. And Charles does nothing to suggest otherwise. Historians have long speculated that Charles may well have relished his martyrdom, in the end at least; an impression which is reinforced by the refusal of Brenton's Charles to accept Cromwell's proposed 'settlement' at their Cotton house meeting. When Cromwell suggests that they 'are all on a dark path', Charles replies 'Not I. I am in the light of Heaven, I am God's anointed and all is clear to me' (89). During his final months he was obsessed with George Herbert's Devotions. With an eerie prescience John Donne had preached on the martyrdom of kings at Charles's coronation, the chosen text being 'The last thing Christ bequeathed to thee was his blood, refuse not to go to him but the same way too, if His Glory require that sacrifice'. ${ }^{108}$ This was certainly the kind of king and the kind of martyrdom encountered by those who, in their hundreds and thousands, purchased copies of the Eikon in February and March 1649; the sentiment of a man who, as he touched the edge of the axe which would cut of his head, retained the presence of mind to declare, famously, that he was passing from a 'corruptible to an incorruptible Crown, where no disturbance can be'. ${ }^{109}$ It is also the role which, in the end, Brenton assigns to his Charles Stuart.

It might be supposed that the attempt to humanise the distinctly un-romantic Cromwell would be more challenging still. Even his admirers have, down the ages, struggled with this particular brief. ${ }^{110}$ As the acerbic Richard Baxter observed shortly after Cromwell's death, 'no man was better or worse spoken of than he'. ${ }^{111}$ Carlyle's Cromwell was heroic, but hardly loveable, and much the same might be said of the various Cromwells fashioned by later historians. ${ }^{112}$ Samuel Rawson Gardiner would try to soften the Carlylean Cromwell at the very end of the nineteenth century, applauding the 'greatest because the most typical Englishman of all time'. ${ }^{113}$ Gardiner's Cromwell was a little more human; but not a lot more. Marvell, as we have seen, found it easier to create a 'force of heaven' than a human being. 'Is he a man at all?' Brenton's Charles wonders in resonant terms, when he first hears

\footnotetext{
106 In Act 3 Scene 2 of Richard II, the doomed Richard, at II.54-55, observes to Bolingbroke that 'Not all the water in the rough rude sea/Can wash the balm off from an anointed king'.

107 For a compelling and influential statement on the religious dynamics of the civil wars, see J.Morrill, The Nature of the English Revolution, (Longman, 1993), 33-68.

108 J.Donne, Selected Prose, (Penguin, 1987), 291. For a commentary on this prescience, see Wedgwood, King, 14-15.

109 See Wedgwood, King, 192, and Robertson, Brief, 200.

110 See for example Antonia Fraser, Cromwell, 700-714, striving to reconcile the 'darker' evidently more 'manic' Cromwell with a man who could on occasion display not just considerable personal 'charm' but a remarkable 'tenderness' for those under his charge.

111 In Fraser, Cromwell, 699.

112 On the creation of so 'many Cromwells', see Hill, Englishman, 257-60. On the difficulties of writing about Cromwell the man, as opposed to Cromwell the hero or indeed anti-hero, see Morrill, 'Cromwell and his contemporaries', in Morrill, Cromwell, 259-81.

113 In Hill, Englishman, 259.
} 
that Cromwell would like to meet, 'Or just a force' (54). Brenton does not make his Cromwell any more loveable. But he does, in answer, try to make him more human, a man who likes a drink indeed, who is haunted by indecision and uncertainty, prone to 'episodes of depression', but also a man who understands politics, a 'knocker-together of heads' ${ }^{114}$ And a man who can in one breadth evince the strongest possible faith in the providential indications of the Lord Almighty, but in the next exhibit utter scorn when Charles confirms his belief that he is, by consequences of his anointment, answerable only to God: 'You believe God gave you power over all the rest of us because of a dribble of sticky stuff on your head?' Be 'damned'. It is 'magic stuff, superstition' (88). It was the same sentiment, and the same fear of damnation, which fired Milton's angry denunciation of the Eikon Basilike in the late summer of 1649.

It is the sceptical, perhaps even the angry, Cromwell that England in late 1648 so desperately needs, the knocker-together of heads. ${ }^{115}$ As the play opens pretty much everyone, on the Parliamentarian side at least, sees Cromwell as the only hope. But 'God's Englishman' is up in Knottingley, enjoying a bit too much Yorkshire 'ale', musing on the nature of 'hatred' and 'listening for the voice of providence' $(21,27-30) .{ }^{116}$ In the end it is the voice of Fairfax who persuades him that it is time to return to London and get back to some 'politicking' (31). And yet still Cromwell dithers, forever waiting on the Lord, and events. Much of the first Act is spent just waiting, and much of the second too. Be 'blithe', an anxious Ireton is advised, as the trial of the King commences and things quickly start to go awry, 'Dice are thrown, we all tumble, to come up face or not' (66). Cromwell does pause to contemplate the England that he is trying to build. Having reflected on the text, from Numbers 13:18, 'And what the land is that they dwell in', he muses 'Yes, what is the land we dwell in? What is it to be? Kingdom? Republic, like in Roman times? Democracy, like some lunatics in the Army dream of, all things held in common?' (83) But there are only the questions, and the texts, and the endless 'waiting' upon the Lord.

Such characterisation can trigger rather different critical perceptions. It leads Michael Billington to conclude that Brenton's Cromwell is a 'thundering great hypocrite'; a perception that echoes Richard Baxter's famous observation that the Lord Protector was only too ready to justify any 'fault in a case of necessity'. ${ }^{117}$ The reviewer in Time Out conversely thought they detected a man who, if not exactly loveable, was still possessed of 'charisma and conscience'. ${ }^{118}$ The confusion is entirely understandable. Perceptions of the 'historical' Cromwell continue to conflict, so it is hardly surprising if perceptions of the 'dramatic' do much the same. And it is of course precisely this confusion, the sense of inner torment, which makes Brenton's Cromwell so intriguing and so compelling. Towards the end of the first Act, as the prospect of the King's trial looms, Cromwell conceives the idea of meeting his adversary, in the hope that he can get behind the actor and engage the man:

\footnotetext{
114 Brenton, '55 Days'.

115 The 'frantic enthusiast' perhaps, as David Hume famously termed him. See Hill, Englishman, 258.

116 Historians have contemplated the extent to which Cromwell was deliberately staying his hand, waiting in the north to see how events in London unfolded, or perhaps how God chose to direct them. See Hoyle, War, 487.

117 A man who, the disapproving Baxter confirmed, 'thought secrecy a virtue, and dissimulation no vice'. See Fraser, Cromwell, 702-3. For Billington's observation see his review of 55 Days in http://www.theguardian.com/state/2012/oct/25/55-days-review,

118 http://www.timeout.com/london/theatre/55-days.
} 
Within the Royal shell. The hard carapace of ceremony, his claim to a divine right to rule. What man is in there? If I could crack the shell, reach him. Put my hand in his, pull him to me, our faces close. Then we could speak, low, as human beings, both fallen, both redeemed by the Saviour's blood. And despite all the killing and the horror of these past years, we would settle this. With a prayer. A glass of wine. Even a smile. (51)

It is perhaps the closest Cromwell comes to a philosophy of magistracy; the hope that anything might be resolved by the promise of redemption and the facility of a good chat. When later he and Charles meet, Cromwell opens by hoping that they might 'come to understand each other' (85). It is not a hope that resonates much with Charles.

\section{The Ordinary and the Extraordinary}

Brenton is certainly reconciled to the reality of dramatic confliction; indeed, as a 'new' or perhaps now rather older Jacobean, it might be reasonably supposed that he embraces it. Asked more broadly about his 'job', dramatising historical 'moments', Brenton acknowledged the consequential complexities which attend to the necessary alignment of the 'personal' and the 'political'; complexities which so often trigger those moments of comic as well as tragic rupture, moments which seem to defy reason. In regard to the writing of 55 Days, Brenton identified the particular and 'extraordinary moment of hysteria that broke out' when Cromwell and his fellow regicides, faced with signing the death-warrant, descended into a collective fit of giggling and began flicking ink at one another. It might be supposed that the uneasiest head at this particular moment in history was that of the doomed King. The ink-flicking scene suggests otherwise. A number of regicides would later claim that they were bullied into signing the warrant by Cromwell. ${ }^{119}$ If so the apparent levity would indeed have masked a broader collective unease.

The ink-flicking scene serves the same purpose as the famous mirror-shattering scene in Act 4 Scene 1 of Shakespeare's Richard II or the moment when Lear finally breaks down on the 'blasted heath' or when Henry $V$ wanders through camp on the night before Agincourt. It impresses the simple fact that politics, no matter how high, is ultimately a human experience. It might be something done by heroes. But more commonly it is something done by men who are dithery or 'slippery', or both, who may cherish certain principles or beliefs, but who are most likely to settle for just knocking heads together, getting stuff done as best they can, who find themselves far more often reacting to events than trying to shape them. Shakespeare knew this, and so does Brenton. In an exchange in Act 2 Scene 5, Lilburne tries to dissuade Cooke from continuing to serve as chief prosecutor. 'You sadden me', he says, 'I thought you dreamt with us of a better world'. Cooke's response is simple: 'Dreams achieve nothing. We must wake and do as best we can' (77). Another slightly earlier scene is similarly suggestive. Cromwell and Ireton discuss the implications of the Leveller Agreement, more particularly the case for a 'new constitution' founded on the 'sovereignty of parliament' and a principle of 'universal suffrage'; an 'excellent thing' Cromwell agrees, as he peruses the document, before screwing it up and tossing it on the floor. It would 'ruin us all' (35-6).

It is the human dimension which makes the exercise of magistracy and power so uncertain and on occasion so tragic, and which also makes the drama of history so constantly fascinating. 55 Days

\footnotetext{
119 Historians evince varying degrees of scepticism in regard to later regicide protestations. See Royle, War, 496-7.
} 
closes with the moment of Charles's execution on the late morning of January $30^{\text {th }}$. Marvell of course structured his account slightly differently; placing the same moment at the middle of his Ode. But Marvell's purpose was different, and Brenton is not fashioning heroes. There are no heroes in 55 Days; just two leading men, human, flawed, uneasy, thrown together by the most extraordinary of circumstances. The most striking feature of the final scene in Brenton's play is again how simple it is. Marvell's poetry reached its highest point as Charles laid down his 'comely head'. ${ }^{120} 55$ Days closes with Charles fiddling with his hair, and then chatting to his executioner about the best height for the block. ${ }^{121}$ Rarely has the decapitation of a king seemed so very ordinary.

Marvell might have demurred, but it is tempting to assume that Milton would have nodded his approval; except of course that there is a necessary irony in the dramatic presentation of any historical event. Brenton may, like Milton, want to cast down the imagination; but it is precisely the same imagination which he must conjure in order to fill his theatre. As critics have noted, whilst his politics might be undeniably round-headed, there is more than a little of the literary cavalier in Howard Brenton, the hopeful, perhaps even the 'incurable romantic'. ${ }^{122}$ It is the romantic who wants to write history as a history of men and women, and who therefore appreciates that the interests of a progressive politics is sometimes written in poetry as well as prose. Moreover, it is precisely the same imagination which must be conjured if Brenton is to achieve his larger aspiration, to make history speak to the present. In an early interview, a much younger Brenton ventured two reasons why history matters. First because 'of the old truth - that if you don't understand the past, you'll never understand the present, let alone the future', and second because it is 'continually destroyed and lost'. ${ }^{123}$

Both aspirations resonate in regard to 55 Days, written not just to celebrate the birth of English socialism, but to transform our 'vague impressions' of the English revolution into something altogether closer and more informed, to make the revolution and its consequences 'part of our national consciousness'. ${ }^{124}$ One reviewer of 55 Days, though generally admiring, thought it to be 'hard work', like 'attending two double-history lessons at school'. ${ }^{125}$ Perhaps, but such a conclusion does not diminish the importance of the endeavour, or the significance of the writer. It is what a dramatic historian, a writer of 'history plays for now', is supposed to do. ${ }^{126}$ Once again, as we have already noted, whilst 55 Days purports to be about the seven weeks and a day which preceded the execution of Charles I it is about far more than just this. In terms of historical reach, it is about a hundred and fifty years of post-reformation history, and then another four centuries which followed; for whilst Brenton is writing about something that happened in the middle of the seventeenth century, he is also writing about the state of England today, its politics and its constitution.

120 Much as it might be said that Burke's Reflections reached its highest point, at least poetically, with the famous depiction of the 'rape' of Marie Antoinette, which is again found at the very centre of the narrative. 121 It has been surmised that Charles was anxious to ensure that there was no botched execution, as had happened most notoriously in the case of Mary Queen of Scots, when the first blow of the axe had failed to sever the head. The hair was to be properly tucked away so that the executioner had a clear view of the neck. 122 The phrase 'incurable romantic' is put into the mouth of a character in Brenton's Diving for Pearls, and one which Duncan Wu surmises to be possibly testamentary. See his Dramatists, 81, 88-90.

123 Brenton, 'Interview', 136.

124 H.Brenton, '55 Days'.

125 http://telegraph.co.uk/culture/theatre-reviews/9633745/55/55-days-Hampstead.

126 Brenton, 'Interview', 138. 
Discussing his earlier political affiliations, Brenton placed himself with a 'great radical tradition' of British theatre; left-leaning, oppositional, republican to a degree, and accepting of the historical fact that there is always likely to be 'blood in the Revolution's cradle' ${ }^{127}$ The revolution to which Brenton was alluding more particularly was in fact the French, the events of which he had revisited in his adaption of Buchner's Danton's Death. But there is a broader resonance. Contemplating the consequences of the French revolution tends to make writers think rather more about the English. It did Burke and Carlyle too. A different, but no less pertinent, resonance can be heard in the celebrated rejoinder of the Chinese premier Zhou Enlai when asked about the implications of the French revolution. It was, he replied, too early to tell. ${ }^{128}$ The same, it might be argued, could be said of the English. It can certainly be said of the revolution which the audience is invited to contemplate in 55 Days. January $30^{\text {th }} 1649$ might have been a pivotal moment of 'rupture'. But it was the product of a much longer imagining, as we have already noted; and it still is, written and rewritten from one generation of historians to another.

And much the same is true of the constitution which it was supposed, in the grander Whig narrative, to have forged. Christopher Hill, as thoroughly Whiggish as he was socialist and radical, would later declare that January 1649 was the moment when the future constitutional shape of England, as a country 'ruled by Parliaments and not by absolute kings', was 'ensured'. ${ }^{129}$ Other later historians can still be found arguing much the same. David Smith, for example, has recently suggested that the restoration 'settlement' designed by 'constitutional royalists' such as Clarendon owed much to the associated myths of 'ancient' constitutionalism so vigorously recommended by conservative parliamentarians such as Ireton; as well by evasive 'trimmers' such as Andrew Marvell. ${ }^{130}$ And it was this 'settlement' which would be confirmed in 1688; finding expression in those two statutes so revered in Whig historiography, the Bill of Rights and the Act of Settlement. Except of course that it was not to be quite so simple, for the reason which David Hume articulated in his History of England, published in 1754, and which found later, famous, articulation in de Tocqueville's Democracy in America. ${ }^{131}$ The English 'constitution' defies discernment. There might indeed be certain 'fundamental' statutes, many of which were written in the decades following the revolutions of the seventeenth century, and there would be plenty of defining constitutional cases to come, and any number of authoritative treatises, some written by Whig historians and jurists, some written by Tories. But there would be no such thing as a 'written' constitution; which is, of course, precisely as Ireton and Cromwell would have had it.

But it is not what Lilburne wanted. This is not to suppose that the Whiggishly radical Brenton would have aligned himself with the Tory Hume, at least not politically. But he might have shared a measure of Hume's scepticism, along with a similar measure of Lilburne's. He would certainly have

127 See comments made in an interview published in 1987, 'The Red Theatre Under the Bed', 3 New Theatre Quarterly 1987, 196, 200. He had said much the same eight years earlier, declaring that all his 'plays are written unreservedly in the cause of socialism'. See 'Interview', in 3 Performing Arts 1979, 135. See also S.Bennett, 'At the End of the Great Radical Tradition? Recent Plays by Howard Brenton', 33 Modern Drama 1990, 409 and 416, and D.Wu, Six Contemporary Dramatists, (St Martins, 1995), 86.

128 It has been subsequently suggested that Zhou might have misunderstood the question, and assumed that he was being asked about the rather more recent riots in Paris in May 1968. Zhou's comments were made in 1972 during President Nixon's famous visit to China.

$129 \quad$ Hill, Englishman, 253.

130 Smith, Royalism, 297-304, 310-13, 319-20.

131 See here Burgess, Absolute Monarchy, 131-2. 
disputed the presumptions of progress and 'finality' which came to define the intellectual predilections of 'grand' Whiggery. And which, it might be added, continues to underpin the complacency which can be discerned in so much contemporary political and constitutional discourse; the supposition that a liberal constitution might work itself 'pure', that there is an internal rationality which constantly refines legal and governmental process. ${ }^{132}$ Modern liberal jurisprudence commonly evinces a similarly Whiggish faith in certain 'principles' of liberal legalism, the rule of law, the separation of powers, and in the more particular context of the British constitution, the sovereignty of parliament. ${ }^{133}$ Here again Lilburne would have had no issue with the aspiration. It is the complacency against which he would have argued, and the dissimulation.

And exactly the same can be presumed of Brenton; so fiercely castigated, at the turn of the century, for refusing to join 'the bandwagon of pro-Blair adulators' who fawned over the constitutional 'reform' project which encompassed, with varying degrees of celebration, the Human Rights Act, assorted devolution statutes, and then a little later the Constitutional Reform Act of 2005. ${ }^{134}$ The insinuation that New Labour might be little more than a reinvested species of 'grand' Whiggery is intriguing; not least because it suggests a reason why so many of the more radically-inclined, such as Brenton, were so quickly disappointed. Constitutional reform tends to be insular. Social justice requires more than the occasional statute, no matter how 'fundamental' it might pretend to be. Most importantly perhaps it requires committed political and intellectual debate. Brenton's generation of playwrights defined themselves in terms of this commitment, as in a rather different tone did the generation of 'new brutalist' writers which followed in the 1990s. ${ }^{135}$ The apparent return to a more reflective species of political theatre during the previous decade and a half, characterised by its particular interest in testament and history, might appear to betray a lessening of energy, if not commitment. But what it denotes in fact is a strategic reversion. In their return to a distinct species of historical realism, plays such as 55 Days or Anne Boleyn signify, not a lessening of energy, but a return to a kind of theatre that is a little less 'in-yer-face' and a little more 'in-yermind', or maybe 'in-yer-past'. ${ }^{136}$

An immediate and obvious parallel can be made with the reinvestment over the same period of a distinctive genre of documentary or 'verbatim' theatre; so much of which, in seeking to interrogate the particular consequences of ' $9 / 11$ ', has assumed a jurisprudential tone. Here 55 Days might be read as a piece of 'verbatim' historical drama; deploying a variety of testamentary materials in order to contemplate the various responses, political, intellectual, jurisprudential, to the consequences, immediate and longer-term, of a defining moment of 'rupture' in English history. In such a reading

132 On the idea of the liberal constitution working itself 'pure', see most famously Ronald Dworkin, Law's Empire, (Belknap Press, 1986). On the internal, or immanent, rationality of liberal legalism, see E.Weinrib, 'Legal Formalism: On the Immanent Rationality of Law', 97 Yale Law Journal 1988, 949.

133 For a recent example, see here T.Bingham, The Rule of Law, (Allen Lane, 2010).

134 See Reinelt, 'Affinities', 310, and also Edgar, State of Play, 22-6, contemplating the often fraught, invariably complicated relationship which existed between New Labour and radical theatre during the first decade of the twenty-first century.

135 For an interesting commentary on the place of 'new brutalism' within modern radical theatre, see D.Edgar, 'Unsteady States: Theories of Contemporary New Writing', 15 Contemporary Theatre Review 2005, 300-2.

136 For interesting overviews of the state of 'realist', political and 'postmodern' theatre at the turn of the new century, see V.Gottlieb, 'Theatre Today - the new realism', 13 Contemporary Theatre Review 2003, 5-14, and J.Reinelt, 'Politics, Playwriting, Postmodernism: An Interview with David Edgar', 14 Contemporary Theatre Review 2004, 42-53. 
January $30^{\text {th }} 1649$ serves precisely the same purpose as September $11^{\text {th }} 2001$. It matters a bit more than other days, not simply because of what happened at that moment, or indeed what followed in the months and years to come, but because it makes us think rather more not just of then, but of now. In this way history matters to political theatre; for the same reason indeed that it matters to a properly critical jurisprudence. ${ }^{137}$ As the prominent critical legal scholar Allan Hutchinson argued so eloquently back in 1988 :

We are never not in a story. History and human action only take on meaning and intelligibility within their narrative context and dramatic settings... There is no truth nor knowledge outside the dramatic context and idiom of history. All conversations occur within history. ${ }^{138}$

55 Days pivots round a conversation, one that is no less real for being imagined. The conversation between Charles and Cromwell may not have happened in January 1649; at least not how Brenton writes it. But it happens each and every time an audience watches a performance of 55 Days, as it does each and every time a reader reads it. It is a conversation between two very different visions of England, its governance and its constitution. And it is a conversation which is as resonant today as it would have been four and a half centuries ago.

137 As David Edgar has recently argued, part of the 'literal conversation' which constantly and insistently questions how 'our contradictory affinities, histories and identities relate to each other'. See Edgar, State of Play, 34.

138 A.Hutchinson, Dwelling on the Threshold: Critical Essays on Modern Legal Thought, (Carswell, 1988), 13. 